\title{
Exceptional longevity, slow growth and late maturation infer high inherent vulnerability to exploitation for bass groper Polyprion americanus (Teleostei: Polyprionidae)
}

\author{
Corey B. Wakefield*, Stephen J. Newman, Dion K. Boddington
}

Western Australian Fisheries and Marine Research Laboratories, Department of Fisheries, Government of Western Australia, PO Box 20, North Beach, Western Australia 6920, Australia

\begin{abstract}
The bass groper Polyprion americanus is a large demersal teleost $(>1.5 \mathrm{~m})$ that inhabits deep continental and oceanic island slopes (50 to $1000 \mathrm{~m}$ ). Currently, this species is considered Critically Endangered by the IUCN and there is a moratorium on its capture in Brazil. Fishing for this species is no longer commercially viable in Bermuda and they are fully protected in South Africa. In most other locations, this species is rarely encountered and knowledge of its biology and catch history is limited. In the present study, specimens were collected from recreational and commercial catches $(n=151)$ in the southeastern Indian Ocean from 2005 to 2012 . Otolith edge analysis was used to verify that a single opaque zone was deposited annually from May to September. A maximum age of $78 \mathrm{yr}$ for females and $55 \mathrm{yr}$ for males was determined from thin transverse sections of otoliths. The spawning period of this gonochorist was from autumn to early winter (March to June) and partitioned prior to that of the sympatric congener P. oxygeneios (June to September). The lengths and ages at which $50 \%$ of females and males matured were 944 and $808 \mathrm{~mm}$ total length, and 14.4 and $11.2 \mathrm{yr}$, respectively. The exceptional longevity, slow growth and late maturation of $P$. americanus imply a high inherent vulnerability at relatively low levels of exploitation. As such, the overexploitation of P. americanus in both Brazil and Bermuda should warrant close scrutiny in the waters off southwestern Australia, where exploitation of deepwater fisheries resources has increased.
\end{abstract}

KEY WORDS: Life history - Age - Thin otolith sections $\cdot$ Natural mortality Spawning period · Deepwater $\cdot$ Reproduction $\cdot$ Continental slope $\cdot$ Indian Ocean

Resale or republication not permitted without written consent of the publisher

\section{INTRODUCTION}

The bass groper Polyprion americanus (Bloch \& Schneider, 1801), is a large and conspicuous demersal teleost potentially reaching $2 \mathrm{~m}$ in length and a mass of $100 \mathrm{~kg}$ (Roberts 1989). Also called wreckfish and stone bass, $P$. americanus is a marine, bathydemersal and oceanodromous species that exhibits an anti-tropical distribution with a widespread but discontinuous range (Ball et al. 2000, Paulin et al. 2001). It inhabits continental slopes, oceanic islands and seamounts at depths of 50 to $1000 \mathrm{~m}$ (Sedberry et al. 1999, Peres \& Klippel 2003). In the eastern North Atlantic Ocean, $P$. americanus ranges from Norway to northwestern Africa, including the Mediterranean Sea, Canary Islands, Madeira and Cape Verde. This species also inhabits the mid-Atlantic ridge and associated islands (e.g. Azores), and the western North Atlantic Ocean from the Grand Banks, Newfoundland, Canada to the Florida Straits and Bermuda, USA (Sedberry et al. 1999, Sedberry 2002, Sadovy 2003). In the southern hemisphere, this species is 
known from South America (i.e. Uruguay, Argentina and Brazil), New Zealand and Australia (Pacific and Indian Oceans), including Tristan da Cunha in the South Atlantic Ocean and the St. Paul and Amsterdam Islands in the western Indian Ocean (Sadovy 2003).

Ball et al. (2000) reported a wide genetic separation among Polyprion americanus samples from Brazil and the South Pacific (i.e. eastern Australia and New Zealand) similar to the level of genetic separation between $P$. americanus and $P$. oxygeneios, suggesting possible cryptic speciation and the likely existence of a third species of Polyprion. Their study concluded that further clarification of Polyprion systematics was required. Earlier, Roberts (1986) revised the systematics of Polyprion and attributed $P$. moeone as a synonym of $P$. americanus. However, Paxton et al. (1989) reported P. moeone and P. oxygeneios as the only valid species occurring in Australia and New Zealand. More recently, Hoese et al. (2006) and Gomon et al. (2008) have reported $P$. americanus and $P$. oxygeneios as the only valid species occurring in Australia and New Zealand, with $P$. moeone attributed as a synonym of $P$. americanus. Nonetheless, a number of recent studies have revealed cryptic speciation among several taxa, e.g. Etelis carbunculus spp. complex (reported in Andrews et al. 2011) and the Scarus ghobban spp. complex (Choat et al. 2012). Given the ongoing development of genetic sequencing, further examination may redefine Polyprion systematics. As such, while we report here on $P$. americanus, we note that the Australian and New Zealand populations may comprise a separate and distinct species.

Juvenile Polyprion americanus are pelagic until approximately $650 \mathrm{~mm}$ total length $\left(L_{\mathrm{T}}\right)$ and are often found associated with drifting floating objects (Sedberry et al. 1996, 1999, Paulin et al. 2001, Machias et al. 2003). Adults occur in offshore waters around structure and epibenthic habitats to depths of $\sim 1000 \mathrm{~m}$, where temperatures range from about 6 to $16^{\circ} \mathrm{C}$ (Sedberry et al. 1999). The extended juvenile pelagic stage and the possible movement of adult fish (Sedberry et al. 1996, 1999) are both considered mechanisms that potentially contribute to gene flow and thus underpin the genetic similarity among northern hemisphere populations (i.e. eastern North Atlantic, western North Atlantic, Mediterranean Sea) of P. americanus (Ball et al. 2000). However, despite the long juvenile pelagic stage there is no evidence of any gene flow or mixing between northern and southern hemisphere populations (Ball et al. 2000) and $P$. americanus is absent from tropical waters
(Sedberry 2002). Despite pan-oceanic connectivity in the northern hemisphere, $P$. americanus populations in the southern hemisphere between Brazil and the South Pacific are significantly different based on microsatellite genetic markers (Ball et al. 2000).

The age-based life history traits of Polyprion americanus have been investigated in the western North Atlantic (Sedberry et al. 1999, Vaughan et al. 2001) and western South Atlantic (Peres \& Haimovici 2004). Otolith-based age estimates of $P$. americanus obtained from the western South Atlantic yielded maximum observed ages of $76 \mathrm{yr}$ for males and $62 \mathrm{yr}$ for females (Peres \& Haimovici 2004). This exceptional longevity and related life history attributes suggest that $P$. americanus is highly vulnerable to fishing exploitation (Sedberry et al. 1999, Koslow et al. 2000, Sadovy 2003, Cornish 2004). This vulnerability has been demonstrated from its listing by the IUCN as Critically Endangered for the Brazilian subpopulation, where there has been a moratorium on their retention since 2005 (Cornish \& Peres 2003), Perez et al. 2009). In addition, Sedberry et al. (1999 and Sedberry (2002) reported that the harvest of $P$. americanus was considered no longer commercially viable in Bermuda. In most other locations throughout its wide distribution, this species is rarely encountered, knowledge of its biology is limited and there is uncertainty surrounding the potential for undiscovered stocks in deep or remote waters. Subsequently, most populations have been accorded a Data Deficient status by the IUCN (Sadovy 2003).

In southwestern Australian waters, Polyprion americanus is a commercially and recreationally targeted species. Although it comprises only a small proportion of the commercial catch of demersal finfish in the region (with a total catch of $\sim 3 \mathrm{t}$ in the 2009-2010 fishing season), this species is a valuable target of recreational fishers due to its large size and iconic status (Department of Fisheries 2011). Recent stock assessments of inshore demersal fish species raised concerns of overfishing in the metropolitan waters of Perth $\left(\sim 31^{\circ}\right.$ to $33^{\circ} \mathrm{S}$ ) (Wise et al. 2007), and highlighted the potential for shifts in effort to deeper, offshore waters (>200 m). Significant changes to management were introduced to reduce catches of inshore demersal species by all sectors to $50 \%$ of those of the 2005-2006 fishing season. This included the closure of the inshore Metropolitan Area $(<250 \mathrm{~m})$ to commercial line, long-line and demersal gillnet fishing (Wise et al. 2007).

Currently, there is limited information available on the biology of Polyprion americanus from either Australian or New Zealand waters. As such, this study is the first investigation of the length and age composi- 
tions, growth, longevity, natural mortality and reproduction of $P$. americanus in Australia. We sought to obtain quantitative data relating to these life history parameters to satisfy base level information requirements for fisheries management of this species in Western Australia. More specifically, we aimed to (1) determine the frequency of growth zone deposition in otoliths of $P$. americanus using otolith edge analysis to facilitate age estimates; (2) describe the length and age compositions of samples derived from fishing and determine growth rates; (3) confirm that the reproductive mode is gonochoristic in accordance with previous studies (e.g. Roberts 1989); (4) determine the timing of the annual spawning period; and (5) estimate the lengths and ages at which females and males attain sexual maturity. In addition, we reviewed and compared the results obtained from this study with available information relating to these life history characteristics for all Polyprion species.

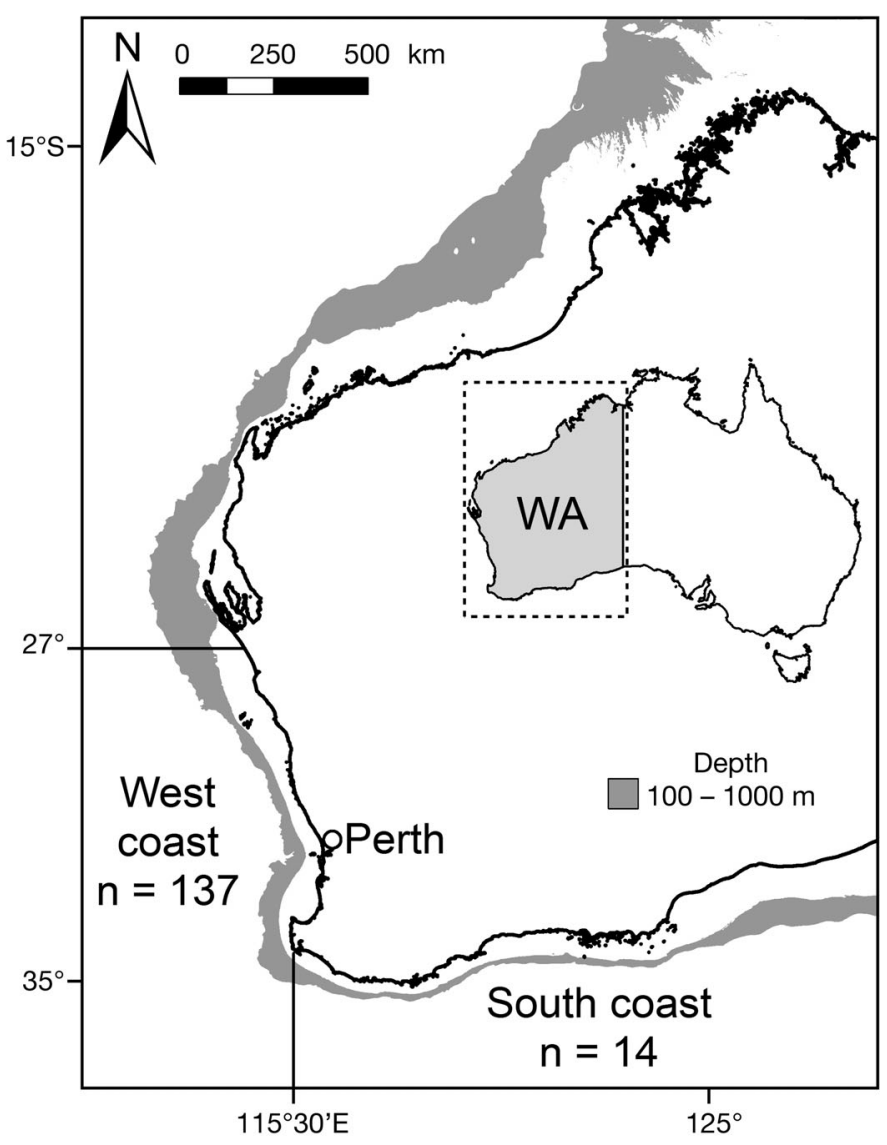

Fig. 1. Polyprion americanus. Areas from which samples were obtained from catches taken by commercial and recreational fishers in southwestern Australia. Sample sizes (n) are shown for the west (south of $27^{\circ} \mathrm{S}$ ) and south (east of $115^{\circ} 30^{\prime} \mathrm{E}$ ) coast management regions in Western Australia (WA). The typical depth range of this species is from 100 to $1000 \mathrm{~m}$

\section{MATERIALS AND METHODS}

\section{Sampling}

Samples $(n=151)$ of Polyprion americanus were obtained from catches taken by commercial and recreational fishers using lines (i.e. drop lines, and rod and reel) from 2005 to 2012 from the west ( $\mathrm{n}=$ $137)$ and south coast $(n=14)$ management regions of Western Australia (Fig. 1). The $L_{\mathrm{T}}$ for each P. americanus was measured to the nearest $1 \mathrm{~mm}$ and when possible the whole weight $\left(W_{\mathrm{W}}\right)$ of each fresh specimen was measured to the nearest $1 \mathrm{~g}$. An allometric relationship between $L_{\mathrm{T}}$ and $W_{\mathrm{W}}$ for females and males combined was derived, such that $W_{\mathrm{W}}=\alpha \times L_{\mathrm{T}}{ }^{\beta}$. Data were log transformed and fitted with a linear regression equation using least squares (Quinn \& Deriso 1999). The equation was used to estimate the weights of $P$. americanus that could not be sampled whole. If gonads were present after frames were donated from fishers, gonadal weight $\left(W_{\mathrm{G}}\right)$ was measured to the nearest $0.01 \mathrm{~g}$, and the individual was sexed and assigned a macroscopic stage of maturation (see below). The sagittae of each P. americanus were removed, cleaned and stored dry.

\section{Age, growth and natural mortality}

The right sagitta of each fish was embedded in epoxy resin and sectioned transversely through its primordium in a direction perpendicular to the sulcus acusticus, using a low speed saw with a diamond tipped blade (Newman 2002, Wakefield \& Newman 2008). Otolith sections were cut thin (i.e. between 0.11 and $0.15 \mathrm{~mm}$, Peres \& Haimovici 2004), and then polished against 2000-grade wet and dry emery paper on a flat surface under tap water to improve growth zone clarity. Sections were mounted on glass slides with a cover slip using casting resin. Otolith sections were viewed under reflected light through a compound microscope fitted with a dark field filter to enhance contrast at 40 to $100 \times$ magnification. On each otolith section, counts of opaque zones were obtained primarily along an axis from the primordium to the crista superior (dorsal rim of sulcus acusticus). These counts were performed without any knowledge of the size of the fish from which the otoliths were from.

Otolith edge analysis was used to determine the periodicity of growth zone formation and to confirm that a single opaque zone is deposited annually (Sedberry et al. 1999, Peres \& Haimovici 2004). The margin of each otolith section was categorised as either 
thin translucent (i.e. $<50 \%$ width of preceding translucent zone), wide translucent (i.e. $>50 \%$ width of preceding translucent zone) or opaque (see Newman \& Dunk 2003, Wakefield et al. 2010). The percentage occurrences of the different otolith margin categories for each calendar month were used to determine the timing of opaque and translucent zone deposition in otoliths.

A large proportion of the otolith sections $(93 \%, \mathrm{n}=$ 129) were examined independently by 2 readers (C.B.W. and S.J.N.). The precision of opaque zone counts between readers was compared using the Index Average Percent Error (IAPE, Beamish \& Fournier 1981). The age of each Polyprion americanus was estimated using a combination of the birth date, the time of year when the opaque zones on the otoliths of the majority of $P$. americanus become delineated, and the number of opaque zones. The birth date of $P$. americanus was considered to be relative to the commencement of the spawning period (i.e. $1 \mathrm{March}$ ) as determined from the annual trends in gonadosomatic indices and macroscopically staged gonads. The growth characteristics of female and male $P$. americanus were described using the von Bertalanffy growth equation fitted to age and length data, such that $L_{t}=L_{\infty}\left(1-\exp ^{-k\left(t-t_{0}\right)}\right.$, where $L_{t}$ is the predicted mean total length ( $\mathrm{mm}$ ) of fish at age $t(\mathrm{yr}), L_{\infty}$ is the asymptotic mean length $(\mathrm{mm}), k$ is the the growth coefficient, a constant that determines the rate at which $L_{t}$ approaches $L_{\infty}\left(\mathrm{yr}^{-1}\right), t$ is the estimated age (yr), and $t_{0}$ is the hypothetical age (yr) at which fish would have zero length. The growth of females and males were compared using a likelihood-ratio test (Cerrato 1990).

The instantaneous rate of natural mortality $(M)$ was derived using the maximum age of females and males within the general regression equation of Hoenig (1983) for fish mortality: i.e. $\log _{\mathrm{e}} Z=1.46-$ $1.01 \log _{\mathrm{e}} t_{\mathrm{max}}$, where $Z$ is the total mortality rate and $t_{\max }$ is the maximum age (yr). The Hoenig (1983) equation has been found to provide a reasonable approximation of $M$ for demersal teleosts (Hart \& Russ 1996, Newman et al. 1996, 2000).

\section{Reproduction}

During dissection all gonads were assigned a maturation stage from macroscopic examination based on Wakefield et al. (2010). These stages included: Stage I: immature/resting; Stage II: developing; Stage III: developed; Stage IV: ripe/spawning; and Stage V: spent. Subsamples of freshly dissected ova- ries $(n=7)$ and testes $(n=5)$ were preserved in $\mathrm{pH}$ neutral $10 \%$ buffered formalin to examine maturity stages using histology and confirm that the reproductive mode of this species is gonochoristic (Roberts 1989, Peres \& Klippel 2003). Medial transverse sections of the preserved gonads were embedded in paraffin wax, sectioned at $5 \mu \mathrm{m}$, mounted on slides and stained with Mayer's haematoxylin and eosin. Gonadosomatic indices (GSI) were calculated for females and males using the equation GSI = $100\left(W_{\mathrm{G}} / W_{\mathrm{W}}\right)$. The spawning period of Polyprion americanus was assessed using annual trends in GSI and macroscopic staging of gonad maturation.

The lengths at which Polyprion americanus reached maturity were determined using data from the months when fish contained developing, developed or spent gonads (i.e. Stages II to V). The lengths at which $50 \%$ of female and male $P$. americanus each attained sexual maturity $\left(L_{50}\right)$ were determined using a reparameterised form of the logistic equation (e.g. Punt \& Kennedy 1997, Wakefield et al. 2007), to describe the relationship between length and the probability that a fish during the spawning period possessed maturing or mature gonad stages (Stages II to V). It was assumed that during the spawning period, fish with gonads at these stages had the potential to spawn, were spawning or had recently spawned and that fish with gonads at Stage I remained immature. The reparameterised logistic equation used was:

$$
P_{\mathrm{L}}=\left\{1+\exp \left[-\log _{\mathrm{e}}(19)\left(L_{\mathrm{T}}-L_{50}\right) /\left(L_{95}-L_{50}\right)\right]\right\}^{-1}
$$

where $P_{\mathrm{L}}$ is the proportion of mature $P$. americanus at a particular total length $L_{\mathrm{T}}$, and the $L_{50}$ and $L_{95}$ are the estimated total lengths at which 50 and $95 \%$ of female and male $P$. americanus attained sexual maturity. This logistic equation was fitted by maximising the sum of the log-likelihoods such that, on the basis of its $L_{\mathrm{T}}$, an immature (Stage I) fish would have a likelihood of $P_{\mathrm{L}}$ and a mature (Stages II to V) fish a likelihood of $1-P_{\mathrm{L}}$. Values of the $L_{50}$ and $L_{95}$ and their $95 \%$ confidence intervals (CI) were determined by bootstrapping, with replacement, from each data set to generate 2000 estimates of the parameters of the logistic equation. The parameters and $95 \% \mathrm{CI}$ for the reparameterised logistic equation were calculated as the median, upper and lower 2.5 percentiles of the 2000 bootstrap estimates of each length class. Estimates of the age at which $50 \%$ of female and male $P$. americanus matured were calculated for each sex separately by using the $L_{50}$ values within the von Bertalanffy growth equations. 


\section{RESULTS}

\section{Length-weight relationship}

In total, 151 Polyprion americanus were collected, which included 60 females, 60 males and 31 individuals for which sex could not be determined due to missing gonads upon receipt from fishers. Whole weights were obtained for 35 individuals, providing an estimated length-weight relationship, for both sexes combined, of $W_{\mathrm{W}}=0.00007819 L_{\mathrm{T}}^{2.8028}\left(\mathrm{r}^{2}=\right.$ 0.89 , range $=638$ to $1452 \mathrm{~mm} L_{t}$ ). The smallest female P. americanus sampled was $776 \mathrm{~mm}$ and $8.1 \mathrm{~kg}$ and the smallest male was $563 \mathrm{~mm}$ and $4.0 \mathrm{~kg}$. The longest female sampled was $1452 \mathrm{~mm}$ and weighed $51.9 \mathrm{~kg}$ and the heaviest female weighed $55.2 \mathrm{~kg}$ and measured $1415 \mathrm{~mm}$. The largest male (in both length and weight) was $1342 \mathrm{~mm}$ and $53.7 \mathrm{~kg}$.

\section{Otolith growth zone formation and ageing precision}

Otolith sections of Polyprion americanus with wide translucent outer margins (i.e. $>50 \%$ of the width of the preceding translucent zone) were recorded exclusively from January to April (Fig. 2). Individuals with an opaque outer margin on their otoliths were first recorded in May, and continued to be present in some individuals through to September (Fig. 2). Newly delineated opaque zones were evident follow-

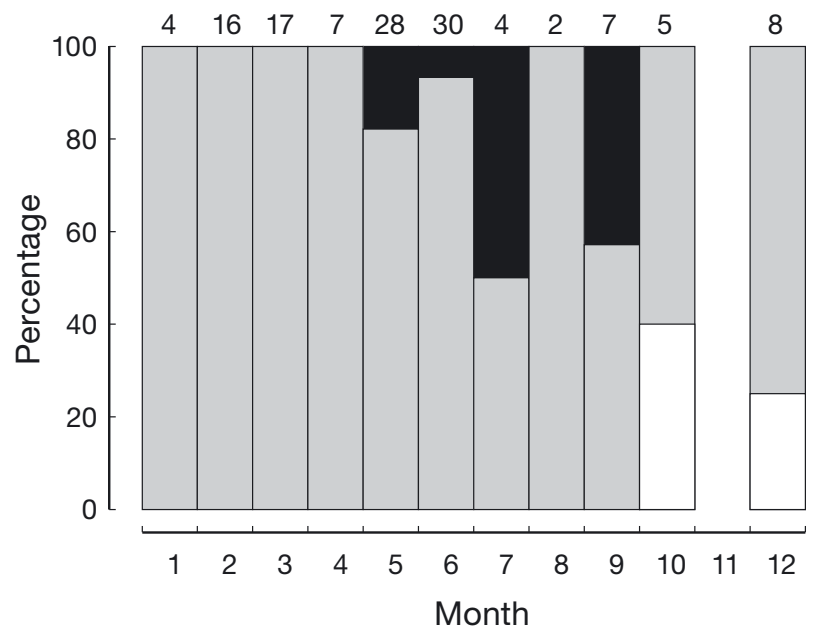

Fig. 2. Polyprion americanus. Monthly percentage contributions of the 3 categories of outer margin of sectioned otoliths. White: thin translucent $(<50 \%$ width of preceding translucent zone), grey: wide translucent ( $>50 \%$ width of preceding translucent zone); black: opaque. Sample sizes are shown above each month ing the deposition of a thin translucent zone (i.e. $<50 \%$ of the width of the preceding translucent zone) at the outer margin. Otoliths with a thin translucent zone on the outer margin were recorded in October and December, and thus in the 3 mo following the period when otoliths possessed an opaque outer margin (Fig. 2). The annual trend exhibited in the classification of the outer margin of otoliths of $P$. americanus, over the full range of opaque zone counts, demonstrated that a single opaque zone is deposited each year from late autumn to early spring (i.e. May to September). Therefore, counts of opaque zones from transverse sections of the sagittal otoliths were used in calculating the age of $P$. americanus from southwestern Australia.

The precision of opaque zone counts from thin transverse sections of otoliths between the two readers was high with an IAPE of $3.72 \%(n=129$, age range 5 to $77 \mathrm{yr}$ ). Opaque zone counts by the secondary reader concurred with or differed by 1 for $55 \%$ of the counts made by the primary reader. Most counts differed by $<4$ rings ( $88 \%$ ) and no counts differed by $>7$ rings. Counts from these sections were reexamined by both readers to reach a consensus that was used in subsequent analyses. The 2 readers' counts were identical for the otolith section with the highest number of opaque zones (i.e. 77). In general, the readability of most otolith sections was good, with the high level of precision among independent readings indicating that both readers interpreted the otoliths of Polyprion americanus in a similar manner.

\section{Length and age compositions, growth and natural mortality}

The $L_{\mathrm{T}}$ of female Polyprion americanus ranged from 764 to $1452 \mathrm{~mm}$ with a general unimodal distribution at the 1100 to $1149 \mathrm{~mm}$ length class (Fig. 3). In comparison, $L_{\mathrm{T}}$ values of male $P$. americanus were smaller with a range of 563 to $1342 \mathrm{~mm}$ and a general unimodal distribution at the 950 to $999 \mathrm{~mm}$ length class (Fig. 3). These differences in length composition between females and males were not reflected in their age compositions. Both female and male $P$. americanus had a similar range in ages, i.e. 9.3 to $53.8 \mathrm{yr}$ for females and 5.7 to $54.7 \mathrm{yr}$ for males, with the exception of 2 old females of 63.3 and $77.7 \mathrm{yr}$ (Fig. 3). The greater difference in length compositions between sexes, when compared to age compositions, likely reflects differences in growth. The von Bertalanffy growth curves fitted to length-at-age data (between 10 and 55 yr) differed significantly 


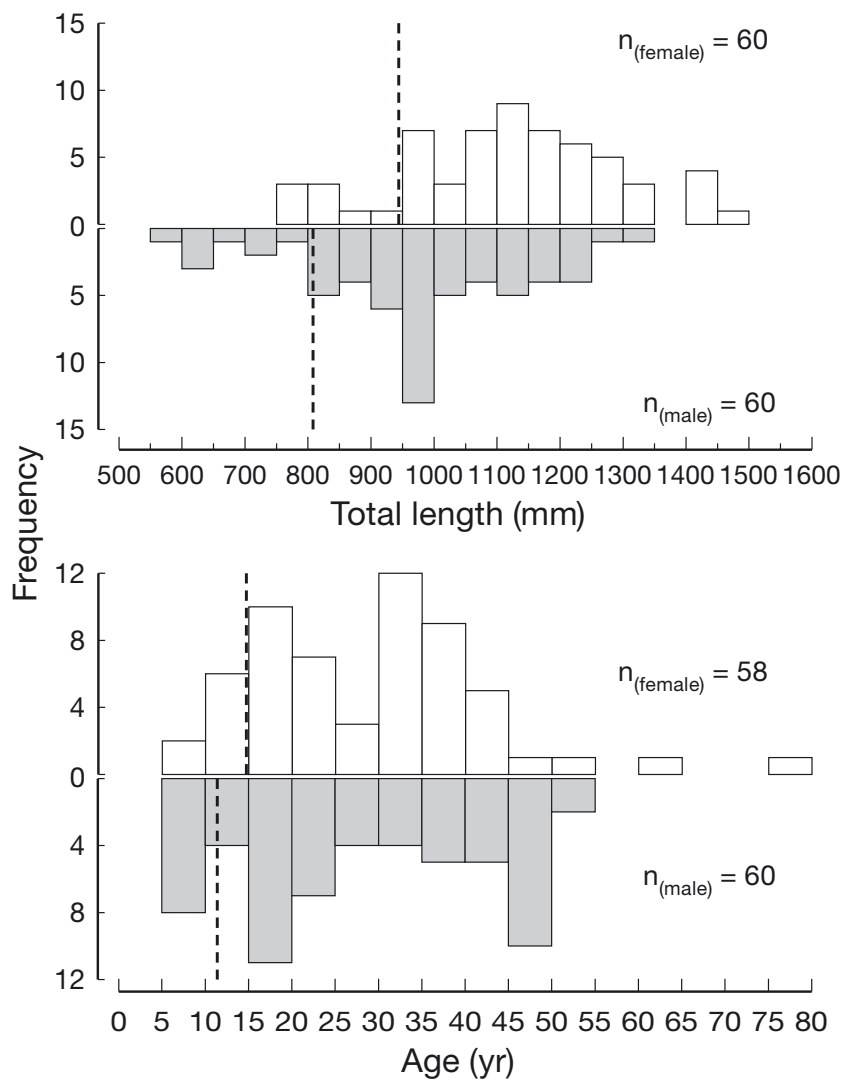

Fig. 3. Polyprion americanus. Length and age frequency histograms for females (white bars) and males (grey bars). Dashed lines represent estimated lengths and ages at 50\% maturity between sexes $(\mathrm{p}<0.05)$. Female $P$. americanus attained a larger length-at-age than males, with the estimated $L_{t}$ from von Bertalanffy growth equations at ages 10, 30 and $50 \mathrm{yr}$ being 782, 1186 and $1247 \mathrm{~mm}$ respectively for females compared to 769, 1068 and $1107 \mathrm{~mm}$ for males (Table 1, Fig. 4). This was also reflected in a larger estimated asymptotic mean length $\left(L_{\infty}\right)$ from the von Bertalanffy growth equations of $1259 \mathrm{~mm}$ for females compared to $1113 \mathrm{~mm}$ for males (Table 1). P. americanus reached a large size at a relatively young age. This was reflected by the estimated weights at 5 and $10 \mathrm{yr}$ of age being 2.8 and $10.0 \mathrm{~kg}$ respectively for females, and 3.6 and $9.6 \mathrm{~kg}$ for males. The estimated $M$ derived from Hoenig's (1983) equation and based on the maximum age of females and males was 0.05 and $0.08 \mathrm{yr}^{-1}$, respectively.

\section{Spawning mode, spawning period and sexual maturity}

The overall sex ratio of Polyprion americanus samples collected in this study was essentially parity. Visual inspection of the external morphology and body colouration of each $P$. americanus provided no evidence of sexual dimorphism or dichromatism. The macroscopic appearance of $P$. americanus ovaries and testes consisted of a distinct central lumen and much narrower testicular sperm duct, respectively.

Table 1. Polyprion spp. Comparison of von Bertalanffy growth function parameters $\left(L_{\infty}, k, t_{0}\right)$, mortality parameters $(Z, M, F)$, longevity and method of growth determination. Sex: Comb. = both sexes combined, $q=$ female, $\sigma^{p}=$ male. TS $=$ transverse sections of otoliths. Derivation of mortality parameters: ${ }^{\mathrm{A}}$ estimates of total mortality $Z$ derived from age composition data; ${ }^{\mathrm{H}}$ estimates of natural mortality $M$ such that $Z=M$ for an unfished stock, derived from the equation of Hoenig (1983); ${ }^{C}$ estimates derived from catch data; ${ }^{\mathrm{P}}$ estimates of $M$ derived from the equation of Pauly (1980). Table updated from Wakefield et al. (2010). $L_{\infty}$ : asymptotic mean length; $k$ : growth coefficient; $t_{0}$ : age at zero length; $Z$ : total mortality; $M$ : natural mortality; $F$ : fishing mortality

\begin{tabular}{|c|c|c|c|c|c|c|c|c|c|c|}
\hline \multirow[t]{2}{*}{ Sex } & \multicolumn{3}{|c|}{ Growth parameters } & \multicolumn{3}{|c|}{ Mortality parameters } & \multirow{2}{*}{$\begin{array}{c}\text { Max. } \\
\text { longevity } \\
(y r)\end{array}$} & \multirow{2}{*}{$\begin{array}{c}\text { Method } \\
\text { of } \\
\text { ageing }\end{array}$} & \multirow[t]{2}{*}{ Locality } & \multirow[t]{2}{*}{ Source } \\
\hline & $\begin{array}{c}L_{\infty} \\
(\mathrm{mm})\end{array}$ & $\begin{array}{c}k \\
\left(\mathrm{yr}^{-1}\right)\end{array}$ & $\begin{array}{c}t_{0} \\
(\mathrm{yr})\end{array}$ & $Z$ & $M$ & $F$ & & & & \\
\hline \multicolumn{11}{|c|}{ P. americanus (Bloch \& Schneider, 1801) } \\
\hline ф & 1259 & 0.09 & -0.36 & - & $0.05^{\mathrm{H}}$ & - & 78 & TS & \multirow[t]{2}{*}{ Southwestern Australia } & \multirow[t]{2}{*}{ Present study } \\
\hline $0^{7}$ & 1113 & 0.10 & -1.54 & - & $0.08^{\mathrm{H}}$ & - & 55 & TS & & \\
\hline & 1295 & 0.05 & -6.80 & - & - & - & 62 & TS & \multirow[t]{2}{*}{ Western South Atlantic } & \multirow[t]{2}{*}{ Peres \& Haimovici (2004 } \\
\hline $0^{7}$ & 1095 & 0.08 & -4.69 & - & - & - & 76 & $\mathrm{TS}$ & & \\
\hline Comb. & 1517 & 0.08 & -3.73 & - & - & - & 31 & TS & Western North Atlantic & Sedberry et al. (1999) \\
\hline Comb. & 1638 & 0.03 & -16.56 & - & $0.14^{\mathrm{H}}$ & $\sim 0.2-0.8^{\mathrm{C}}$ & 39 & TS & Western North Atlantic & Vaughan et al. (2001) \\
\hline \multicolumn{11}{|c|}{ P. oxygeneios (Schneider \& Forster, 1801) } \\
\hline Comb. & 890 & 0.24 & -0.63 & $0.10-0.14^{\mathrm{A}}$ & $0.09^{\mathrm{H}}$ & $0.01-0.05$ & 52 & TS & South coast, Western Australia & Wakefield et al. (2010) \\
\hline Comb. & 1317 & 0.07 & -4.63 & - & $0.07^{\mathrm{H}}$ & - & 63 & TS & New Zealand & Francis et al. (1999) \\
\hline ○ & 1761 & 0.09 & 0.17 & - & $0.13^{\mathrm{P}}$ & - & - & - & South Pacific (Juan Fernández & Pavez \& Oyarzŭn (1985) \\
\hline $0^{7}$ & 1449 & 0.10 & 0.06 & - & $0.16^{\mathrm{P}}$ & - & - & - & Archipelago) & \\
\hline
\end{tabular}



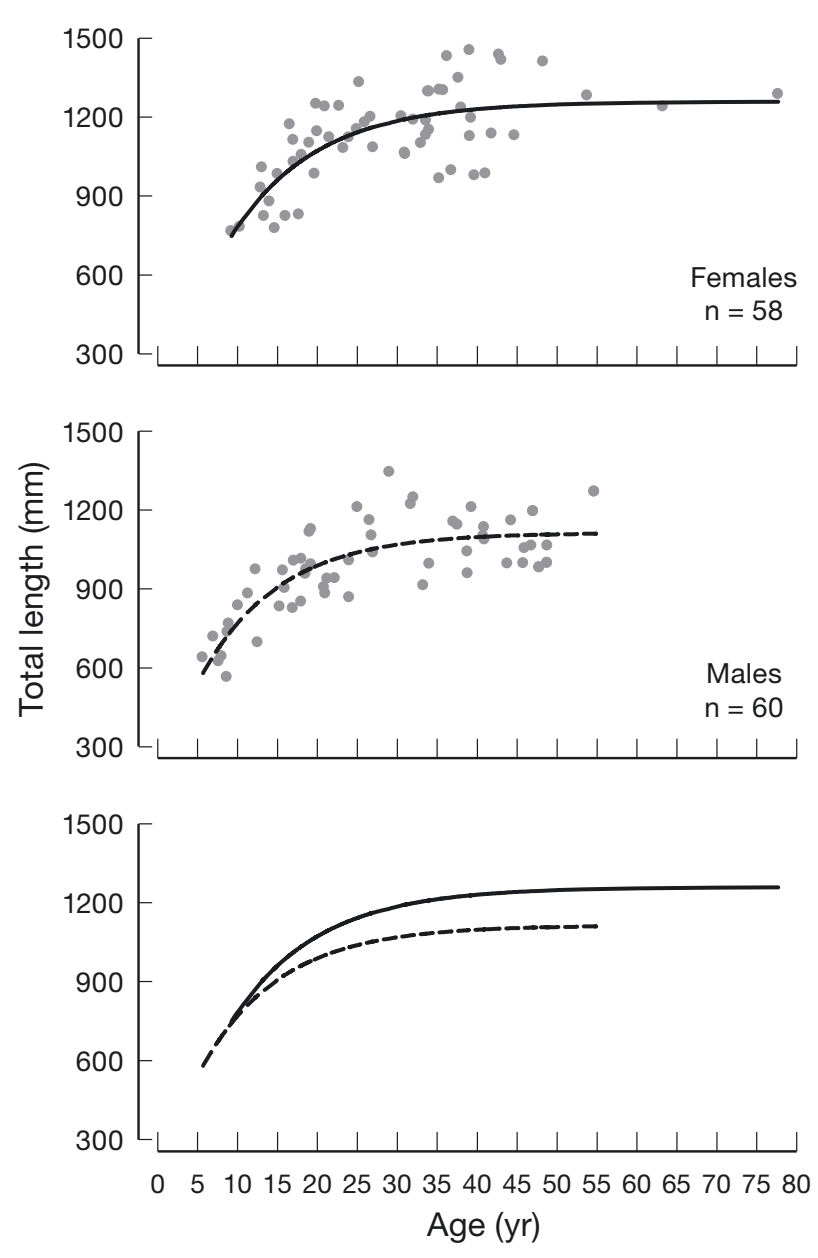

Fig. 4. Polyprion americanus. Age-length relationship for females (solid line, top) and males (dashed line, middle) fitted with von Bertalanffy growth curves, and a comparison of the 2 growth trajectories (bottom)

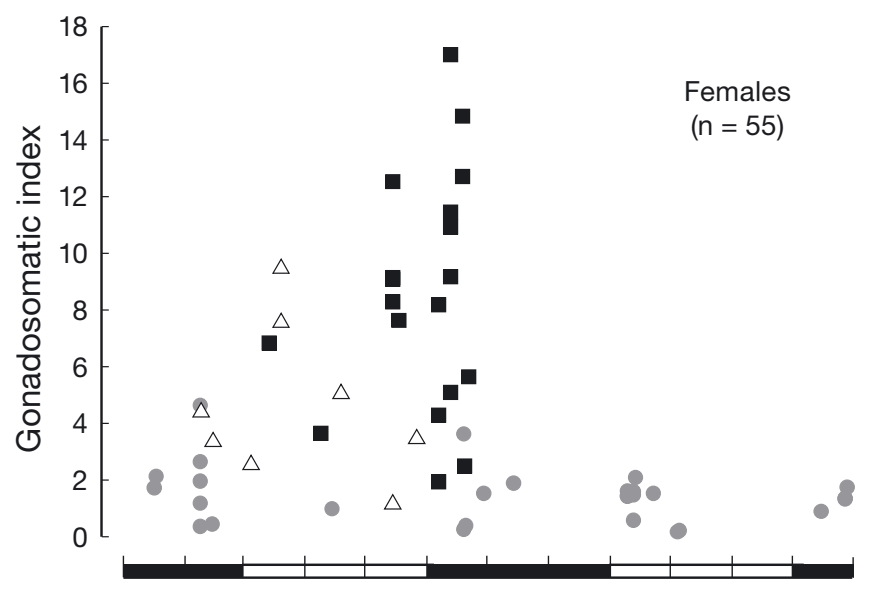

Jan Feb Mar Apr May Jun Jul Aug Sep Oct Nov Dec
Ovaries were distinctly pink to orange and the testes white. Conspicuous blood vessels were present in ovary walls and the large oocytes were obvious in developing, developed and spent ovaries. These macroscopic characteristics allowed for confident distinction between sexes. In addition, histological examination of a subset of gonads revealed no evidence of transitional reproductive tissue, no remnant bisexual characteristics (e.g. lumen in testes), a well differentiated sperm duct (as opposed to a sperm sinus) and only ever testicular or ovarian tissue present in one gonad. Based on these criteria and in accordance with other studies (Roberts 1989, Peres \& Klippel 2003), the reproductive mode of $P$. americanus was confirmed to be gonochoristic.

In January, the GSI and maturation stages of gonads of female and male Polyprion americanus were relatively low ( $<3$ for females and $<1$ for males) and were all immature/resting (Stage I, Fig. 5). Developing gonads were first present in some females and males in February, which was evident from an enlarging of the relative size and firmness of gonads, an increase in oocyte size in ovaries and more apparent white form for the testes (consistent with Stage II, see Wakefield et al. 2010), along with a higher GSI for some individuals (Fig. 5). Individuals possessing developing gonads were observed in female $P$. americanus until May and in males until March. Developed (Stage III) and spawning gonads (Stage IV) were recorded for female and male $P$. americanus from March to June. Individuals with gonads at this stage generally had the highest values of GSI, i.e. $>10 \%$ and $>4 \%$ of body weight for

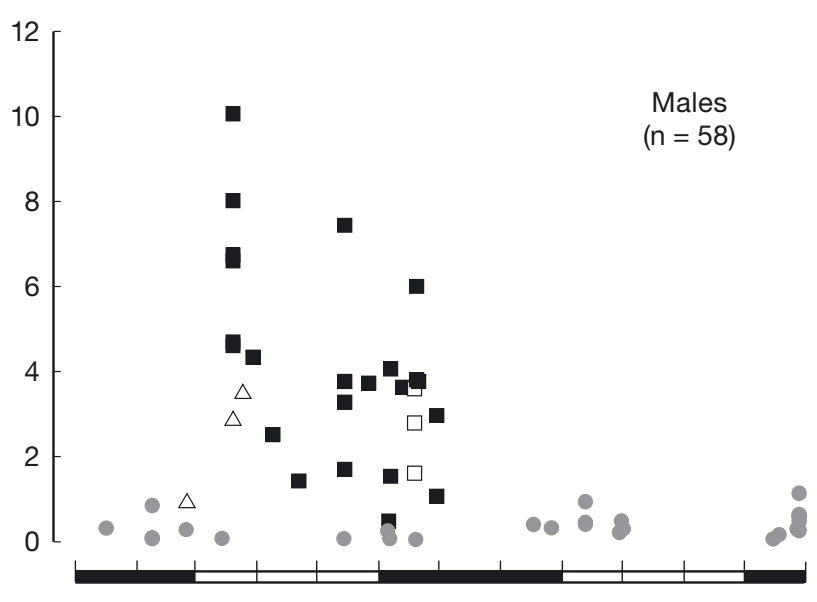

Jan Feb Mar Apr May Jun Jul Aug Sep Oct Nov Dec

Fig. 5. Polyprion americanus. Gonadosomatic indices of females (left) and males (right) with gonads at various stages of maturation. (O) Stage I: immature/resting; $(\Delta)$ Stage II: developing; $(\square)$ Stages III-IV: developed/spawning; $(\square)$ Stage V: spent. On the $x$-axis, black rectangles are summer and winter months and white rectangles are autumn and spring months 
females and males, respectively (Fig. 5). Gonadal regression as indicated by the presence of spent gonads (Stage V) was only observed in three males in June. From July to December, all P. americanus sampled possessed gonads with relatively low GSI values and immature/resting gonads (Stage I) (Fig. 5). Hence, the spawning period of $P$. americanus off southwestern Australia occurs during the austral autumn to early winter, i.e. from March to June.

The smallest mature (i.e. possessing Stage II to V gonads) female and male Polyprion americanus sampled were 930 and $825 \mathrm{~mm} L_{\mathrm{T}}$, respectively. During the spawning period, the prevalence of mature females increased from $0 \%$ in the 800 to $900 \mathrm{~mm}$ length class to $75 \%$ in the 900 to $1000 \mathrm{~mm}$ length class and to $83 \%$ in the 1000 to $1100 \mathrm{~mm}$ length class (Fig. 6). All females $>1100 \mathrm{~mm} L_{\mathrm{T}}(n=20)$ sampled during the spawning period were recorded as mature, with one exception. In comparison, all males $<800 \mathrm{~mm} L_{\mathrm{T}}$ sampled during the spawning period were immature/resting (Stage I). The prevalence of mature males increased to $80 \%$ in the 800 to $900 \mathrm{~mm}$

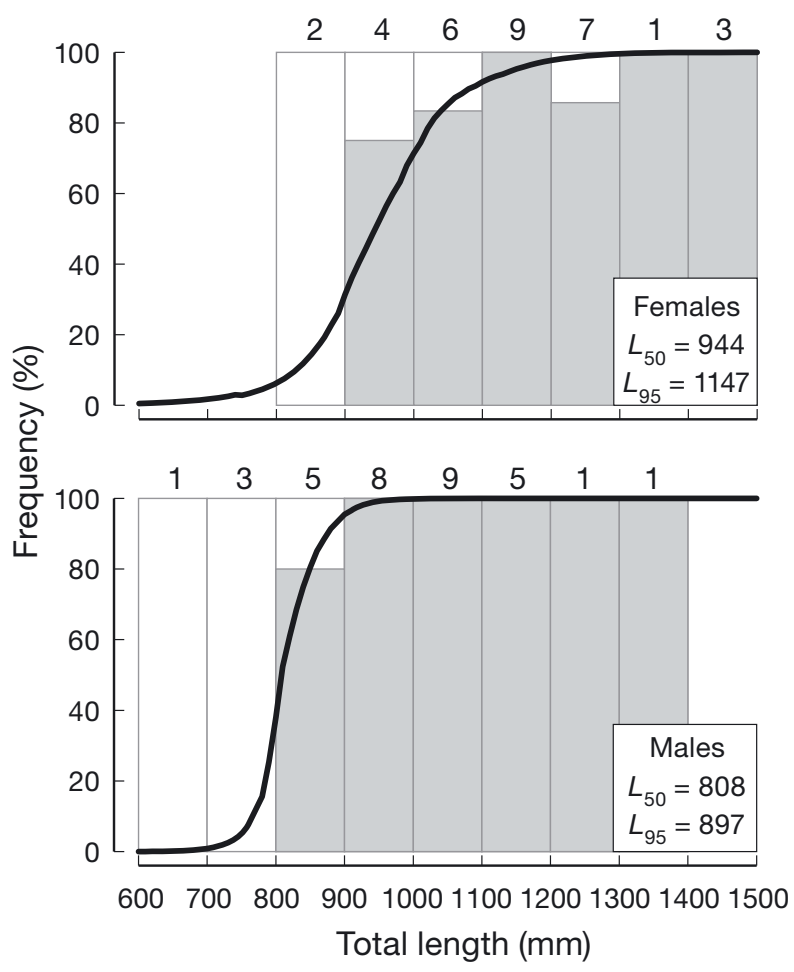

Fig. 6. Polyprion americanus. Frequency of immature (white) and mature (grey) females and males collected during the spawning season (March to June). Sample sizes are shown above each month. Curves represent the expected percentage of mature individuals as determined from logistic regression analysis. $L_{50}$ and $L_{95}$ : length at 50 and $95 \%$ maturity, respectively length class, with all males $(\mathrm{n}=24)>900 \mathrm{~mm} L_{\mathrm{T}}$ recorded as mature (Fig. 6). The maturation of females at a larger size than males was reflected in values for $L_{50}$, i.e. 944 (684 to $1038 \mathrm{~mm} 95 \% \mathrm{CI}$ ) versus $808 \mathrm{~mm}$ (892 to $1461 \mathrm{~mm} \mathrm{95 \%} \mathrm{CI,} \mathrm{Fig.} \mathrm{6).} \mathrm{The} \mathrm{estimated} \mathrm{ages}$ at which $50 \%$ of female and male $P$. americanus reach sexual maturity were calculated using $L_{50}$ values in the respective inverse von Bertalanffy growth equations to be 14.4 and $11.2 \mathrm{yr}$, respectively.

\section{DISCUSSION}

This is the first study of the life history characteristics of Polyprion americanus in Australian waters. Sample sizes of $P$. americanus were only available in small numbers when compared to those of other teleosts that were sampled from the same commercial and recreational catches (e.g. Wakefield et al. $2010,2013)$. It is uncertain whether this lower relative abundance in catches reflects the natural abundance of this species on the continental slope off southwestern Australia, or that higher abundances of this species occur at greater depths than were fished during the period of collection for this study. The depths at which $P$. americanus were sampled ranged from 250 to $600 \mathrm{~m}$, although depths of capture were not always included in the catch information provided by fishers. Nonetheless, sufficient quantities were obtained from most months, including those when this species spawns, and over a wide length and age range, to elucidate life history characteristics relating to age, growth, natural mortality and reproduction. The results of this study, along with related studies of the life history traits of $P$. americanus and Polyprion species in general (Tables 1 \& 2), allow us to characterise the likely population parameters in this data-limited group and thus also construct a risk profile for this species.

\section{Size-, age- and growth-based life history traits}

The length range of Polyprion americanus sampled in this study ( 560 to $1450 \mathrm{~mm} L_{\mathrm{T}}$ ) was very similar to those described from the western North Atlantic (750 to $1460 \mathrm{~mm}$, Sedberry et al. 1999) and western South Atlantic Oceans (440 to $1560 \mathrm{~mm}$, Peres \& Haimovici 2004). In each study, the smallest individual sampled most likely reflects the length at which this species settles from pelagic habitats as a juvenile to demersal habitats as an adult (Machias et al. 2003), rather than selectivity associated with the various fishing gears 
Table 2. Polyprion spp. Comparison of the spawning period, length and age at maturity and reproductive mode. Sex: Comb. $=$ both sexes combined. Maturity: $L_{\mathrm{T}}=$ total length, $L_{50}=$ length at $50 \%$ maturity, $A_{50}=$ age at $50 \%$ maturity, vB $=$ estimated age at $50 \%$ maturity calculated using $L_{50}$ in the von Bertalanffy growth equation

\begin{tabular}{|c|c|c|c|c|c|c|}
\hline Spawning period & Sex & $\begin{array}{l}\text { Matu } \\
L_{50}\left(\mathrm{~mm} L_{\mathrm{T}}\right.\end{array}$ & rity- $A_{50}(\mathrm{yr})$ & $\begin{array}{l}\text { Reproductive } \\
\text { mode }\end{array}$ & Locality & Source \\
\hline \multicolumn{7}{|c|}{ P. americanus (Bloch \& Schneider, 1801) } \\
\hline $\begin{array}{l}\text { Austral autumn to } \\
\text { early winter (Mar-Jun) }\end{array}$ & $\begin{array}{l}\stackrel{9}{9} \\
0^{1}\end{array}$ & $\begin{array}{l}944 \\
808\end{array}$ & $\begin{array}{l}14.4(\mathrm{vB}) \\
11.2(\mathrm{vB})\end{array}$ & Gonochorist & $\begin{array}{l}\text { Southwestern } \\
\text { Australia }\end{array}$ & Present study \\
\hline $\begin{array}{l}\text { Austral mid-winter to } \\
\text { mid-spring (Jul-Oct) }\end{array}$ & $\begin{array}{l}9 \\
0 \\
0^{\prime 1}\end{array}$ & $\begin{array}{l}779 \\
749\end{array}$ & $\begin{array}{l}10.4(\mathrm{vB}) \\
9.0(\mathrm{vB})\end{array}$ & Gonochorist & $\begin{array}{l}\text { Western South } \\
\text { Atlantic, Brazil }\end{array}$ & Peres \& Klippel (2003) \\
\hline $\begin{array}{l}\text { Boreal winter to spring } \\
\text { (Nov-May) }\end{array}$ & Comb. & - & $\sim 8-10$ & - & $\begin{array}{l}\text { Eastern North } \\
\text { Atlantic, USA }\end{array}$ & Sedberry et al. $(1999,2006)$ \\
\hline- & - & - & - & Gonochorist & New Zealand & Roberts (1989) \\
\hline \multicolumn{7}{|c|}{ P. oxygeneios (Schneider \& Forster, 1801) } \\
\hline $\begin{array}{l}\text { Austral winter to } \\
\text { early spring (Jun-Sep) }\end{array}$ & $\begin{array}{l}\text { 잉 } \\
0^{7}\end{array}$ & $\begin{array}{l}760 \\
702\end{array}$ & $\begin{array}{l}7.1 \\
6.8\end{array}$ & Gonochorist & $\begin{array}{c}\text { South coast, } \\
\text { Western Australia }\end{array}$ & Wakefield et al. (2010) \\
\hline $\begin{array}{l}\text { Austral winter to } \\
\text { early spring (Jun-Sep) }\end{array}$ & - & - & - & Gonochorist & $\begin{array}{l}\text { East coast, } \\
\text { New Zealand }\end{array}$ & $\begin{array}{l}\text { Beentjes \& Francis (1999), } \\
\text { Roberts (1989) }\end{array}$ \\
\hline
\end{tabular}

used among studies. An extended pelagic juvenile life history strategy appears consistent among Polyprion species (Roberts 1996), with the pelagic juveniles attaining up to $\sim 650 \mathrm{~mm} L_{\mathrm{T}}$ for $P$. americanus (Machias et al. 2003) and $670 \mathrm{~mm} L_{\mathrm{T}}$ and $4 \mathrm{yr}$ of age for P. oxygeneios (Roberts 1996, Francis et al. 1999). This extended juvenile phase and their affinity with drifting floating objects during this period has been suggested as one potential mechanism for panoceanic mixing among populations, in addition to adult migration (Massuti et al. 1999, Riera et al. 1999, Ball et al. 2000).

Ageing precision error of Polyprion americanus based on counts of opaque zones from thin otolith transverse sections was $3.72 \%$ and thus within acceptable bounds (i.e. IAPE $<5.5 \%$, Campana 2001). This ageing precision error was also within previous estimates for long-lived deepwater teleosts from the same continental slope locations in southwestern Australia, i.e. 1.95 and $4.89 \%$ (Wakefield et al. 2010, 2013). All age-based studies of $P$. americanus and the congeneric $P$. oxygeneios have found that a single opaque and successive translucent zone is deposited annually in their sagittal otoliths, and that counts of these alternating growth zones can be used to derive age estimates (i.e. Francis et al. 1999, Sedberry et al. 1999, Peres \& Haimovici 2004, Wakefield et al. 2010). The present study found such opaque zones were deposited in the otoliths of $P$. americanus predominantly through the austral winter (i.e. from May to September). This growth zone periodicity was similar to the congeneric $P$. oxygeneios from New Zealand
(Francis et al. 1999) and Western Australia (June to October, Wakefield et al. 2010). It does however differ from that reported for $P$. amercianus from the western South Atlantic (November to February, Peres \& Haimovici 2004).

The longevity of Polyprion americanus was found to differ among locations, with estimates in the southern hemisphere of $76 \mathrm{yr}$ from the western South Atlantic Ocean (Peres \& Haimovici 2004) and 78 yr from the southeastern Indian Ocean (this study), almost double that recorded from the northern hemisphere (39 yr in North Atlantic, Sedberry et al. 1999, Vaughan et al. 2001). The lifespan determined from this study was also greater than those of the congeneric $P$. oxygeneios from New Zealand (63 $\mathrm{yr}$, Francis et al. 1999) and Western Australia (52 yr, Table 1, Wakefield et al. 2010). However, the heaviest $P$. americanus sampled in this study $(54 \mathrm{~kg}$ ) was half that recorded for this species from New Zealand (107 kg, Roberts 1986). Larger specimens were observed by the authors at commercial fish markets, but were not available for sampling. Thus, $P$. americanus may live to more than $78 \mathrm{yr}$ in southwestern Australian waters.

The growth of Polyprion americanus differed between sexes, with females attaining a larger lengthat-age than males at ages $>10$ yr. Females of this species also grew larger than males from the western South Atlantic Ocean (Table 1, Peres \& Haimovici 2004), but this difference was less pronounced for the congeneric P. oxygeneios (Pavez \& Oyarzún 1985, Wakefield et al. 2010). The mean growth of male 
$P$. americanus between these 2 populations in the southern hemisphere (i.e. Brazil and southwest Australia) were very similar (Fig. 7, Peres \& Haimovici 2004); and, although the shape of the von Bertalanffy growth curves for females between these studies differed, their asymptotic mean lengths $\left(L_{\infty}\right)$ were similar (1119 vs. $1095 \mathrm{~mm}$, see Table 1). However, in the western North Atlantic Ocean this species attained much larger predicted lengths than both southern hemisphere populations at the same ages (Fig. 7, Sedberry et al. 1999). Interestingly, the greatest genetic separation among populations within the large global distribution of $P$. americanus is the division at the equator (Sedberry et al. 1996, Ball et al. 2000). To date, P. americanus stocks within the North Atlantic are considered essentially a single population and genetically distinct from those in the southern hemisphere. The systematics and connectivity of this species within their circumglobal distribution in the southern hemisphere is still uncertain and awaiting further investigation following the inclusion of Indian Ocean samples (Ball et al. 2000). The predicted mean growth of $P$. americanus in southwestern Australia increased rapidly during early post settlement up to maturation. This was evident by females and males of this species, on average, reaching $80 \%$ of their estimated $L_{\mathrm{T}}$ at their maximum age by 18 and $14 \mathrm{yr}$, respectively. The mean increase in length for both females and males after these ages

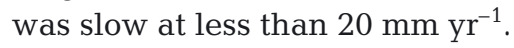

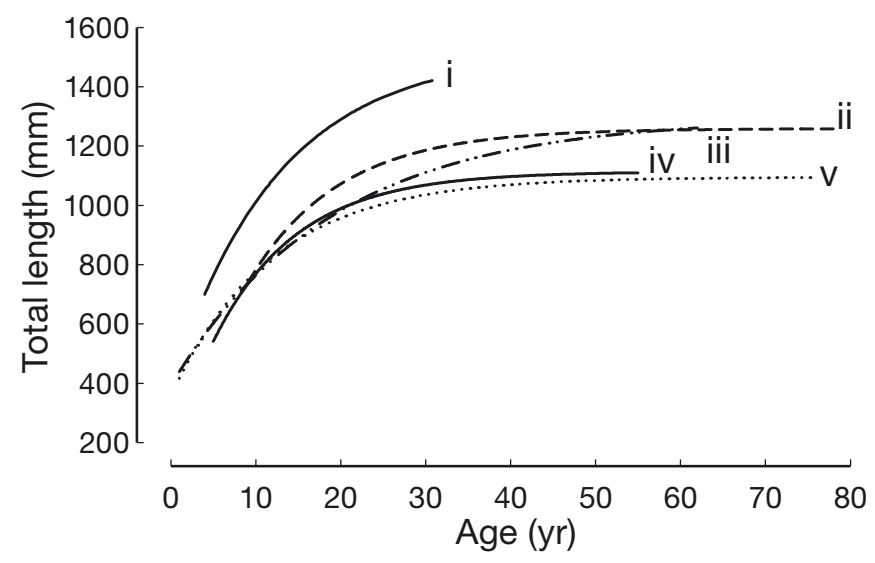

Fig. 7. Polyprion americanus. von Bertalanffy growth curves for (i) the western North Atlantic Ocean (Sedberry et al. 1999); (ii) females, southeastern Indian Ocean (present study); (iii) females, western South Atlantic Ocean (Peres \& Haimovici 2004); (iv) males, southeastern Indian Ocean; (v) males, western South Atlantic Ocean. Note, data is shown only for studies where the growth function parameter $t_{0}$ (i.e. the hypothetical age at which fish would have zero length) did not vary from zero by $>7$ yr (see Table 1)

\section{Reproduction}

The spawning period for Polyprion americanus from southwestern Australia was autumn to early winter (March to June). This spawning period was clearly partitioned earlier than that of the sympatric congener $P$. oxygeneios from essentially the same locations (June to September, Wakefield et al. 2010). As both species of Polyprion are thought to form spawning aggregations (Beentjes \& Francis 1999, Cornish \& Peres 2003), it is likely that such partitioning would result in reduced competition for resources between aggregated spawning adults and also of their early stage progeny. Unfortunately, the resolution of spatial information collected from catches of adults during the spawning period during this study was insufficient to determine spawning locations or relative abundances. The spawning seasonality of $P$. americanus in Australia appears consistent with results from other regions: spawning occurs during the austral winter to spring in the western South Atlantic (July to October, Peres \& Klippel 2003) and the boreal winter to spring in the western North Atlantic (November to May, Table 2, Sedberry et al. 2006). This similarity is surprising considering competition from $P$. oxygeneios would be present in the southern but not the northern Atlantic. However, this could result from $P$. americanus being more abundant and thus likely outcompeting $P$. oxygeneios in the western South Atlantic Ocean, based on abundances from commercial catches in Brazil (e.g. Barreiros et al. 2004). This contrasts the situation in southwestern Australia, where $P$. oxygeneios is more abundant than $P$. americanus in commercial catches and occupies the more typical spawning season expressed by Polyprion species, i.e. from winter to spring (Wakefield et al. 2010).

The lengths at which $50 \%$ of female and male $P$. americanus matured in southwestern Australia were substantially greater than those estimated for this species in the western South Atlantic (see Table 2). These differences were also reflected in higher estimates of the ages at which $50 \%$ of $P$. americanus matured off southwestern Australia (11 to $14 \mathrm{yr}$ ) compared to both the western North Atlantic (8 to $10 \mathrm{yr}$ ) and western South Atlantic Oceans (9 to $10 \mathrm{yr}$, Table 2, Sedberry et al. 1999, Peres \& Klippel 2003). The ages at which $50 \%$ of $P$. americanus matured in southwestern Australia were greater than those estimated for $P$. oxygeneios from the same area $(7 \mathrm{yr}$, Wakefield et al. 2010), and for most demersal teleosts from continental shelf waters along this coastline (4 to $7 \mathrm{yr}$, e.g. Hesp et al. 2002, Wakefield 2006). The 
late maturation of $P$. americanus was however not exceptional, as some demersal teleosts from this coastline are known to mature at older ages (>14 yr, Coulson et al. 2009, 2012).

\section{Management implications}

The deepwater Polyprion americanus is long-lived, slow growing, late maturing and is likely to form spawning aggregations. These life history characteristics typically infer that this species exhibits a high inherent vulnerability to fishing exploitation. The long life span and estimated low natural mortality rate of this species (0.05 to $0.08 \mathrm{yr}^{-1}$, Table 1, Hoenig 1983) indicate a low production potential and limited capacity for exploitation. Although the current exploitation level of $P$. americanus in Western Australia is uncertain, even low levels of fishing effort may result in the reduction of significant levels of spawning biomass of this species.

The high inherent vulnerability of Polyprion americnaus has been demonstrated from fishing exploitation in Brazil, where this subpopulation is now considered Critically Endangered as defined by the IUCN, and a moratorium on their capture has been in place since 2005 (Cornish \& Peres 2003, Perez et al. 2009). Furthermore, harvest of $P$. americanus is no longer commercially viable in Bermuda following depletion from overfishing (Sedberry et al. 1999, Sedberry 2002). Similar to the Brazilian subpopulation, governance of the exploitation of $P$. americanus in South Africa is also highly conservative, with this species being fully protected following suspected declines in catches in recent years (Heemstra \& Heemstra 2004).

The retention of Polyprion americanus from fishing is currently permitted in Western Australia (WA). The state-managed commercial fisheries for the offshore demersal teleost resources on the west coast of WA are controlled by limited access. In addition, there has been a nominal total annual effort allocation of $100 \mathrm{~d}$ for the combined fishing fleet since 2009 (Department of Fisheries 2011). This total effort allocation is monitored using a satellite-based vessel monitoring system on all vessels. $P$. americanus have only been recorded in state-managed commercial catches since 2003, according to compulsory statutory catch returns. However, considering catches of $P$. oxygeneios have been recorded since 1986, it is likely that $P$. americanus may have been misidentified for its congener. Nonetheless, from 2003 to 2010 annual catches of $P$. americanus have averaged $4.4 \mathrm{t}$

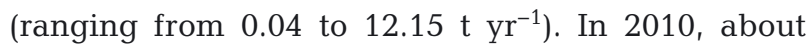
$84 \%$ of offshore effort entitlement in the West Coast Demersal Fisheries was utilised, with only $12 \mathrm{t}$ of offshore demersal species retained. Of this $12 \mathrm{t}, P$. americanus accounted for $2.2 \mathrm{t}$. In comparison, the commercial take of offshore demersal teleosts from the south coast of WA is not subject to such fisheryspecific management regulations, i.e. it remains open access with no effort or catch quota. However, catches of $P$. americanus from this coast are much lower, averaging only $0.5 \mathrm{t} \mathrm{yr}^{-1}$ (ranging from 0.02 to $0.95 \mathrm{t} \mathrm{yr}^{-1}$ ). Interestingly, the ratio of the average annual catch of $P$. americanus between the west and south coasts of Western Australia (8.8:1.0) is very similar to the ratio of samples sizes collected during this study (9.8:1.0).

Considering the depths this species inhabits, traditional management strategies for recreational fishers such as bag, boat and size limits for single species within a multi-species fishery are not likely to be effective, given the likely high rate of mortality associated with barotrauma. Current management arrangements for recreational fishers in WA set a combined bag limit of 2 fish from a list of high risk demersal species that occupy the continental slope (offshore demersal), for each recreational fishing from boat license. In addition, a closure to fishing for demersal species is in place each year along the west coast of WA from 15 October to 15 December, which was implemented as one of the management responses to historically high levels of exploitation of the demersal shelf species (Wise et al. 2007). The period of this demersal closure does not overlap with the spawning period of Polyprion americanus or the congeneric $P$. oxygeneios, which may be important considering these species are likely to form spawning aggregations.

Polyprion americanus is also harvested by the Commonwealth-managed Western Deepwater Trawl Fishery (WDWTF) and Great Australian Bight Trawl Sector (GABTS), which operate in waters adjacent to, or overlapping the west and south coast statemanaged fisheries, respectively, in depths between $200 \mathrm{~m}$ and the boundary of the Australian Fishing Zone (AFZ). Catch statistics from these Commonwealth fisheries are not reported separately for $P$. americanus (Emery et al. 2009, Wilson et al. 2010), and are thus presumably a small component of the catches and likely to be listed under 'total other bony fish' or potentially included within the category 'Hapuku ( $P$. oxygeneios)'. The catches of this latter group appears relatively low, averaging $0.1 \mathrm{t} \mathrm{yr}^{-1}$ from 2000 to 2006 from the WDWTF (Emery et al. 
2009). Therefore, a conservative estimate of the combined catch of $P$. americanus from State and Commonwealth fisheries in southwestern Australia in recent years appears to be less than $10 \mathrm{t} \mathrm{yr}^{-1}$. From a global perspective, the estimated total annual catch from southwestern Australia is markedly lower than that taken for this species in New

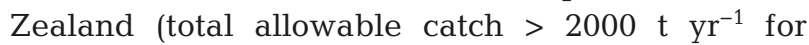
Polyprion spp), Portugal (165 to $406 \mathrm{t} \mathrm{yr}^{-1}, 1989$ to 1998), eastern America (declined from $576 \mathrm{t}$ in 1992 to $70 \mathrm{t}$ in 2000) and Brazil (>1000 $\mathrm{t} \mathrm{yr}^{-1}$ from 1989 to 1998, Cornish \& Peres 2003, Sadovy 2003). This is not surprising as the WA coast is dominated by the nutrient poor, poleward flowing Leeuwin current and receives little inflow from the limited and old weathered riverine systems, resulting in a low productive marine ecosystem and low levels of sustainable catches (Molony et al. 2011). The annual catches from southwestern Australia however are within the range of those reported from the relatively small fishery in Bermuda, which experienced a rapid decline in catches and subsequent commercial extinction. Catches in that fishery dropped from $5.1 \mathrm{t}$ in 1981 to $0.2 \mathrm{t}$ (only 9 fish) in 1996 (and to only 6 fish in 1997) and were associated with the introduction of longlines over historic vertical line fishing (Sedberry et al. 1999, Sadovy 2003).

Due to the difficulty in obtaining sufficient samples of Polyprion americanus, data for stock assessments will be limited to using trends in catch and effort statistics as an index of abundance, with a very limited capacity for synthesis with fishing mortality estimates derived from age compositions. This is likely to result in a higher level of uncertainty around the stock status of $P$. americanus in southwestern Australia. Based on the information presented in this study, and in light of the numerous global examples of the overexploitation of $P$. americanus, both state and Commonwealth-based fisheries managers may need to reassess current management strategies or consider implementing additional management measures (e.g. spatio-temporal closures during the spawning periods of Polyprion species from March to September) in the offshore waters of southwestern Australia to ensure the sustainability of this vulnerable species. Future assessments of this species would benefit from an improved understanding of the taxonomy of this species group, resolution of the connectivity of southern hemisphere stocks, further investigation of longevity in lightly exploited populations and potential use of bomb radiocarbon techniques to confirm age estimations in Indian Ocean samples.
Acknowledgements. The authors extend their gratitude to managers and staff at local fish markets and commercial and recreational (particularly S. Downs, R. Thipthorp and M. Buxcey) fishers for their assistance with the collection of samples. Thank you also to the master and crew of the Department of Fisheries RV 'Naturaliste' for their hard work and accommodation during the numerous offshore surveys. Thank you to H. Mee and S. Cutler for sectioning of otoliths, and to B. Molony and D. Fairclough for their constructive comments on an earlier version of this manuscript. Logistic and financial support for this study was provided by the Department of Fisheries, Western Australia.

\section{LITERATURE CITED}

Andrews AH, Kalish JM, Newman SJ, Johnston JM (2011) Bomb radiocarbon dating of three important reef-fish species using Indo-Pacific $\Delta^{14} \mathrm{C}$ chronologies. Mar Freshw Res 62:1259-1269

Ball AO, Sedberry GR, Zatcoff MS, Chapman RW, Carlin JL (2000) Population structure of the wreckfish Polyprion americanus determined with microsatellite genetic markers. Mar Biol 137:1077-1090

- Barreiros JP, Machado L, Hostim-Silva M, Sazima I, Heemstra PC (2004) First record of Polyprion oxygeneios (Perciformes: Polyprionidae) for the south-west Atlantic and a northernmost range extension. J Fish Biol 64:1439-1441

Beamish RJ, Fournier DA (1981) A method for comparing the precision of a set of age determinations. Can J Fish Aquat Sci 38:982-983

Beentjes MP, Francis MP (1999) Movement of hapuku (Polyprion oxygeneios) determined from tagging studies. NZ J Mar Freshw Res 33:1-12

Campana SE (2001) Accuracy, precision and quality control in age determination, including a review of the use and abuse of age validation methods. J Fish Biol 59:197-242

> Cerrato RM (1990) Interpretable statistical tests for growth comparisons using parameters in the von Bertalanffy equation. Can J Fish Aquat Sci 47:1416-1426

Choat JH, Klanten OS, van Herwerden L, Robertson DR, Clements KD (2012) Patterns and processes in the evolutionary history of parrotfishes (Family Labridae). Biol J Linn Soc 107:529-557

Cornish A (2004) Stereolepis gigas. In: IUCN (2009) IUCN Red List of threatened species, version 2012.2. www. iucnredlist.org

Cornish AS, Peres MB (2003) Polyprion americanus (Brazilian subpopulation). In: IUCN (2012) IUCN Red List of threatened species, version 2012.2. www.iucnredlist.org

Coulson PG, Hesp SA, Hall NG, Potter IC (2009) The western blue groper (Achoerodus gouldii), a protogynous hermaphroditic labrid with exceptional longevity, late maturity, slow growth, and both late maturation and sex change. Fish Bull 107:57-75

Coulson PG, Potter IC, Hall NG (2012) The biological characteristics of Scorpis aequipinnis (Kyphosidae), including relevant comparisons with those of other species and particularly of a heavily exploited congener. Fish Res 125-126:272-282

Department of Fisheries (2011) State of the fisheries and aquatic resources report 2010/11. Fletcher WJ, Santoro K (eds) Department of Fisheries, Perth

Emery T, Brown M, Auld S (2009) Western deepwater trawl fishery data summary 2008. Australian Fisheries Man- 
agement Authority, Canberra

Francis MP, Mulligan KP, Davies NM, Beentjes MP (1999) Age and growth estimates for New Zealand hapuku, Polyprion oxygeneios. Fish Bull 97:227-242

Gomon M, Bray D, Kuiter R (2008) Fishes of Australia's southern coast. Reed New Holland, Chatswood

Hart AM, Russ GR (1996) Response of herbivorous fishes to crown-of-thorns starfish Acanthaster planci outbreaks. III. Age, growth, mortality and maturity indices of Acanthurus nigrofuscus. Mar Ecol Prog Ser 136:25-35

Heemstra P, Heemstra E (2004) Coastal fishes of southern Africa. National Inquiry Services Centre, Grahamstown

Hesp SA, Potter IC, Hall NG (2002) Age and size composition, growth rate, reproductive biology, and habitats of the West Australian dhufish (Glaucosoma hebraicum) and their relevance to the management of this species. Fish Bull 100:214-227

Hoenig JM (1983) Empirical use of longevity data to estimate mortality rates. Fish Bull 82:898-903

Hoese DF, Bray DJ, Paxton JR, Allen GR (2006) Fishes. In: Beesley PL, Wells A (eds) Zoological catalogue of Australia, Vol 35. Australian Biological Resources Study \& CSIRO Publishing, Highett

Koslow JA, Boehlert GW, Gordon JDM, Haedrich RL, Lorance P, Parin N (2000) Continental slope and deepsea fisheries: implications for a fragile ecosystem. ICES J Mar Sci 57:548-557

Machias A, Somarakis S, Papadroulakis N, Spedicato MT, Suquet M, Lembo G, Divanach P (2003) Settlement of the wreckfish (Polyprion americanus). Mar Biol 142:45-52

Massuti E, Morales-Nin B, Deudero S (1999) Fish fauna associated with floating objects sampled by experimental and commercial purse nets. Sci Mar 63:219-227

Molony BW, Newman SJ, Joll L, Lenanton RCJ, Wise B (2011) Are Western Australian waters the least productive waters for finfish across two oceans? A review with a focus on finfish resources in the Kimberley region and north coast bioregion. J R Soc West Aust 94:323-332

Newman SJ (2002) Growth, age estimation and preliminary estimates of longevity and mortality of the Moses perch, Lutjanus russelli (Indian Ocean form), from continental shelf waters off north-western Australia. Asian Fish Sci 15:283-293

Newman SJ, Dunk IJ (2003) Age validation, growth, mortality and additional population parameters of the goldband snapper (Pristipomoides multidens) off the Kimberley coast of northwestern Australia. Fish Bull 101:116-128

Newman SJ, Williams DM, Russ GR (1996) Variability in the population structure of Lutjanus adetii (Castelnau, 1873) and L. quinquelineatus (Bloch, 1790) among reefs in the central Great Barrier Reef, Australia. Fish Bull 94: 313-329

> Newman SJ, Cappo M, Williams DM (2000) Age, growth and mortality of the stripey, Lutjanus carponotatus (Richardson) and the brown-stripe snapper, L. vitta (Quoy and Gaimard) from the central Great Barrier Reef, Australia. Fish Res 48:263-275

Pauly D (1980) On the interrelationships between natural mortality, growth parameters, and mean environmental temperature in 175 fish stocks. J Conseil 39:175-192

Paulin C, Stewart A, Roberts C, McMilan P (2001) New Zealand fish. A complete guide. Te Papa Press, Wellington

Pavez P, Oyarzún ME (1985) Determinación de eficiencia relativa de espineles y parámetros de crecimiento del bacalao de Juan Fernández (Polyprion oxygeneios Bloch y Schneider, 1801), en las islas Robinson Crusoe y Santa Clara. In: Arana P (ed) Investigaciones marinas en e Archipielago de Juan Fernández. Escuela de Ciencias del Mar, Universidad Católica de Valparaiso (in Spanish with English Abstract)

Paxton JR, Hoese DF, Allen GR, Hanley JE (1989) Zoological catalogue of Australia, Vol 7. Pisces. Petromyzontidae to Carangidae. Australian Government Publishing Service, Canberra

> Peres MB, Haimovici M (2004) Age and growth of southwestern Atlantic wreckfish Polyprion americanus. Fish Res 66:157-169

> Peres MB, Klippel S (2003) Reproductive biology of southwestern Atlantic wreckfish, Polyprion americanus (Teleostei: Polyprionidae). Environ Biol Fishes 68:163-173

Perez JAA, Pezzuto PR, Wahrlich R, Soares ALS (2009) Deep-water fisheries in Brazil: history, status and perspectives. Lat Am J Aquat Res 37:513-541

Punt AE, Kennedy RB (1997) Population modelling of Tasmanian rock lobster, Jasus edwardsii, resources. Mar Freshw Res 48:967-980

Quinn TJ, Deriso RB (1999) Quantitative fish dynamics. Oxford University Press, New York, NY

Riera F, Grau A, Grau AM, Pastor E, Quetglas A, Pou S (1999) Ichthyofauna associated with drifting floating objects in the Balearic Islands (western Mediterranean). Sci Mar 63:229-235

Roberts CD (1986) Systemics of the percomorph fish genus Polyprion Oken, 1817. PhD Thesis, Victorian University of Wellington

Roberts CD (1989) Reproductive mode in the percomorph fish genus Polyprion Oken. J Fish Biol 34:1-9

Roberts CD (1996) Hapuku and bass: the mystery of the missing juveniles. Seafood New Zealand 4:17-21

Sadovy Y (2003) Polyprion americanus. In: IUCN (2012) IUCN Red list of threatened species, version 2012.2. www.iucnredlist.org

Sedberry GR (2002) Polyprionidae. Wreckfishes (giant sea basses). In: Carpenter KE (ed) The living marine resources of the Western Central Atlantic, Vol 2: bony fishes, Part 1 (Acipenseridae to Grammatidae). FAO species identification Guide for Fishery Purposes and American Society of Ichthyologists and Herpetologists Special Publication No 5. FAO, Rome

Sedberry GR, Carlin JL, Chapman RW, Eleby B (1996) Population structure in the pan-oceanic wreckfish, Polyprion americanus (Teleostei: Polyprionidae), as indicated by mtDNA variation. J Fish Biol 49:318-329

Sedberry GR, Andrade CA, Carlin JL, Chapman RW and others (1999) Wreckfish Polyprion americanus in the North Atlantic: fisheries, biology, and management of a widely distributed and long-lived fish. Am Fish Soc Symp 23:27-50

Sedberry GR, Pashuk O, Wyanski DM, Stephen JA, Weinbach P (2006) Spawning locations for Atlantic reef fishes off the southeastern US Proc Gulf Caribb Fish Inst 57: 463-514

Vaughan DS, Manooch CS, Potts JC (2001) Assessment of the wreckfish fishery on the Blake Plateau. Am Fish Soc Symp 25:105-120

Wakefield CB (2006) Latitudinal and temporal comparisons of the reproductive biology and growth of snapper, Pagrus auratus (Sparidae), in Western Australia. PhD Thesis, Murdoch University

Wakefield CB, Newman SJ (2008) Age estimation and 
reproductive status of an exceptionally large blue-eye trevalla (Hyperoglyphe antarctica, Centrolophidae) captured off the south coast of Western Australia. Cybium 32:321-324

Wakefield CB, Moran MJ, Tapp NE, Jackson G (2007) Catchability and selectivity of juvenile snapper (Pagrus auratus, Sparidae) and western butterfish (Pentapodis vitta, Nemipteridae) from prawn trawling in a large marine embayment in Western Australia. Fish Res 85:37-48

> Wakefield CB, Newman SJ, Molony BW (2010) Age-based demography and reproduction of hapuku, Polyprion oxygeneios, from the south coast of Western Australia: implications for management. ICES J Mar Sci 67:1164-1174

Wakefield CB, Newman SJ, Marriott RJ, Boddington DK (2013) Contrasting life history characteristics of the

Editorial responsibility: Benjamin Ruttenberg,

Palmetto Bay, Florida, USA eightbar grouper Hyporthodus octofasciatus (Pisces: Epinephelidae) over a large latitudinal range reveals spawning omission at higher latitudes. ICES J Mar Sci, doi:10.1093/icesjms/fst020

Wilson DT, Curtotti R, Begg GA (eds) (2010) Fishery status reports 2009: status of fish stocks and fisheries managed by the Australian Government. Australian Bureau of Agricultural and Resource Economics - Bureau of Rural Sciences, Canberra

Wise BS, St John J, Lenanton RCJ (2007) Spatial scales of exploitation among populations of demersal scalefish: implications for management. Part 1: Stock status of the key indicator species for the demersal scalefish fishery in the West Coast Bioregion. Fisheries Research Report 163, Department of Fisheries, Perth

Submitted: November 14, 2012; Accepted: February 12, 2013 Proofs received from author(s): March 28, 2013 